\title{
Effects of hydrological cycles and water body connectivity on abundance and co- occurrence of two Neotropical Curculionidae species
}

\author{
Wesley Oliveira de Sousa ${ }^{1 *}$, Nelson Vinicius Sabino Serra ${ }^{2}$, Geane Brizzola dos Santos ${ }^{3}$, Rodrigo Aranda $\left.^{1(}\right)$ \& \\ Marinez Isaac Marques ${ }^{2}$ \\ ${ }^{1}$ Universidade Federal de Rondonópolis, Avenida dos Estudantes, no 5055, CEP: 78736-900, Cidade \\ Universitária, Rondonópolis, $M G$, Brasil. \\ ${ }^{2}$ Prefeitura Municipal de Barra do Garças, Secretaria Municipal de Meio Ambiente, Rua Cel. Antônio Cristino \\ Côrtes, $n^{\circ}$ 1042, CEP: 78600-000, Setor Maria Lúcia (DERMAT), Barra do Garças, MG, Brasil. \\ ${ }^{3}$ Universidade Federal de Mato Grosso, Instituto de Biociencias, Avenida Fernando Correa da Costa, no. 2367, \\ CEP: 78060-900, Boa Esperança, Cuiabá, MG, Brasil. \\ *Corresponding author: entomoi@hotmail.com
}

SOUSA, W.O., SERRA, N.V.S., SANTOS, G.B., ARANDAL, R., MARQUES, M.I. Effects of hydrological cycles and water body connectivity on abundance and co-occurrence of two Neotropical Curculionidae species. Biota Neotropica 22(1): e20211249. https://doi.org/10.1590/1676-0611-BN-2021-1249

\begin{abstract}
The effect of the hydrological cycle on the abundance of adults and larvae of the weevils Cyrtobagous salviniae and Cyrtobagous singularis in the Pantanal was tested and related to the host-plant abundance, limnological variables, and hydrological connectivity of 10 "bays" (lakes and ponds) along the Cuiabá River. Adults and larvae of $C$. salviniae were more abundant than $C$. singularis, and larvae and adult abundance differed significantly both within and between the two species. Adults and larvae of both species were more abundant in connected bays, but only C. salviniae responded to both connectivity and hydrological cycle, with the highest abundances during the high-water and rising-water periods for adults and larvae, respectively. Abundance of $C$. singularis was negatively related to the predominance of $C$. salviniae, and populations of adults and larvae of both species were slightly and negatively related to the limnological variables and host-plant abundance. The results showed that the temporal variation in larval and adult abundance and dominance of $C$. salviniae is influenced by hydrological cycle and connectivity, but not by limnological variables and host-plant abundance.
\end{abstract}

Keywords: Aquatic macrophytes; Coleoptera; interspecific competition; sympatric species.

Efeito do ciclo hidrológico e da conectividade das baías do Pantanal na abundância e co-ocorrência de duas espécies de Curculionidae Neotropical

Resumo: O efeito do ciclo hidrológico sobre a abundância de adultos e larvas dos curculionídeos Cyrtobagous salviniae e Cyrtobagous singularis do Pantanal foi testado e relacionado com a abundância das plantas hospedeiras, variáveis limnológicas e conectividade hidrológica de 10 baías do rio Cuiabá. Os adultos e larvas de C. salviniae foram mais abundantes do que $C$. singularis, e a abundância de larvas e adultos diferiu significativamente intra e interespecificamente. Adultos e larvas de ambas espécies foram mais abundantes em baías conectadas, mas apenas C. salviniae respondeu ao ciclo hidrológico, com a maior abundância de adultos durante o período de cheia, e maior abundância de larvas na enchente. A abundância de $C$. singularis foi relacionada negativamente com a predominância de C. salviniae, e a abundância de adultos e larvas de ambas espécies foi fraca e negativamente relacionada com as variáveis limnológicas e abundância das plantas hospedeiras. Os resultados demonstraram que a variação temporal na abundância de larvas e adultos e a dominância de $C$. salviniae foram influenciadas pela conectividade e ciclo hidrológico, mas não pelas variáveis limnológicas e abundância das macrófitas aquáticas.

Palavras-chave: Espécies simpátricas; Coleoptera; competição interespecifica; macrófitas aquáticas. 


\section{Introduction}

The Pantanal is a Neotropical floodplain influenced by the regular monomodal hydrological cycle, as is common in wetlands of the South American tropics and subtropics. Due to the fluctuation between terrestrial and aquatic phases, the level of the rivers shows a predictable monomodal flood curve, and this hydrological cycle is of fundamental ecological importance (Oliveira \& Calheiros 2000, Junk et al. 2006, Alho et al. 2011, Junk et al. 2011, Penatti, et al. 2015). In the northern region of the Pantanal, periodic flooding occurs during the rainy season in areas along river courses, due to topography, low soil drainage capacity, and pronounced precipitation concentrated in a single period of the year (Junk et al. 1989, Hamilton 2002, Junk et al. 2011). The flood pulse is mainly responsible for changes across the hydrological periods (receding water, dry period, rising water, high water) in the chemical, physical, and biotic components of the aquatic environments of floodplains (Junk 1997, Junk et al. 2006) and the biota responds with morphological, anatomical, physiological, phenological, and ethological adaptations (Junk et al. 2011).

Among the aquatic environments in the Pantanal floodplain, the lakes and ponds, locally known as "bays", are influenced physically, chemically, and biologically by the monomodal hydrological cycle and degree of hydrological connectivity (Thomaz et al. 2003, Wantzen et al. 2005, Girard 2011). The connectivity of Pantanal bays to the main channel ranges from permanently connected bays to those that exchange surface water only during the highest flood peaks (Wantzen et al. 2005). Shifts in hydrological connectivity among different floodplain bays vary with flood intensity, influencing the heterogeneity of habitats and the community distribution and composition at the local and regional levels, as well as population size, segregation of many plant and animal species, and consequently trophic interactions (Pott \& Pott 2000, Hamilton 2002, Alho 2008, Pott 2011).

The Pantanal floodplain bays harbor a complex vegetation mosaic with many species of aquatic macrophytes, of which Eichhornia crassipes (Mart.) Solms. (Pontederiaceae) and Salvinia auriculata Aubl. (Salviniaceae) are the most abundant (Pott \& Pott 2003, Wantzen et al. 2005). These macrophytes significantly affect the ecological attributes of other biological assemblages (Thomaz \& Da Cunha 2010). The vegetation has high productivity rates, with growth depending on the supply of nutrients during high water (Pozer \& Nogueira 2004, Nogueira et al. 2011), and the competition among plants depends on the water level (Murillo et al. 2019).

The temporal variation in the abundance of these plant species limits the population dynamics of oligophagous insects (Junk \& Piedade 1997), e.g., during the dry period, insect populations are sharply reduced due to lack of food, and population densities may become much lower in subsequent hydrological periods (Vieira \& Adis 1992). Co-occurrence and competition between oligophagous insects can be influenced by the hydrological cycle, temporal variations in the growth of aquatic macrophytes, and allocation of resources to phytophagous insects. Therefore, changes across seasonal periods resulting from the waterlevel fluctuations, monomodal hydrological cycle, and variations in connectivity influence the dynamics of the macrophyte community and abundance of co-distributed herbivore species, due to changes in the supply of nutrients for plant growth and of habitats for food or reproduction of herbivores (Neiff \& Poi de Neiff 2003, Thomaz \& Da Cunha 2010, Hernandez et al. 2020).

Studies of the invertebrates associated with aquatic macrophytes in natural environments are restricted to communities or groups that inhabit the submerged parts of these plants (Junk \& Robertson 1997, Takeda et al. 2003, Junk et al. 2006). These organisms increase or decrease in abundance throughout the year, directly influenced by particular characteristics of the seasons, such as variation in rainfall and temperature, stress caused by the hydrological cycle (water-level fluctuations), and degree of connection of the bays to the main river channel, which affect factors such as the dissolved-oxygen content of the water (Franco \& Takeda 2000, 2002, Melo et al. 2002, 2004, Benetti \& Cueto 2004, Clemente et al. 2018, Prellvitz \& Albertoni 2004, Wantzen et al. 2011, Zilli 2012). Little attention has been given to the impacts of the monomodal hydrological cycle, seasonal periods, and hydrological connectivity of these bays on the population attributes of phytophagous insects that inhabit aquatic macrophytes (Agostinho et al. 2000, Gopal et al. 2001, Murphy et al. 2003, Fortney et al. 2004, Pott \& Pott 2004, Loyola et al. 2006).

Cyrtobagous Hustache, 1929 is a genus of aquatic weevils, and its species can be considered good biological models for investigating regional and local ecological patterns and floodplain attributes (e.g., flood periodicity, connectivity, environmental and biological factors), since the genus has a wide geographic distribution in South America and its species are native to Brazil, Bolivia, Paraguay, Uruguay, and Argentina (Wibmer \& O'Brien 1986). It was introduced as a potential control agent of Salvinia spp. in 16 localities outside its native range (Parys \& Johnson 2013), because of its levels of specificity and behavioral and morphological characteristics that promote survival in aquatic environments, feeding underwater on the developing leaf buds and petioles, new leaves, and roots of species of Salvinia Ség. (DeLoach 1975, O’Brien 1976, Forno et al. 1983, Calder and Sands, 1985, May \& Sands 1986, Julien et al. 2002, Tipping \& Center 2005, Madeira et al. 2006).

Considering the impacts of the monomodal hydrological cycle on the population attributes of phytophagous insects that inhabit emergent aquatic macrophytes, this study investigated the effects of the hydrological cycle, hydrological connectivity, host-plant abundance, and limnological variations across four seasonal periods (high water, receding water, dry period, and rising water) on the abundance and co-occurrence of the adults and larvae of two Cyrtobagous species associated with floating mats of Salvinia species in Pantanal floodplain bays. We tested the hypothesis that abundance and co-occurrence in the adults and larvae of two Cyrtobagous species are affected by the monomodal flood pulse and seasonality, predicting that larval and adult abundances would be higher in the high-water than in the dry period, in connected than in non-connected bays, and according to the hostplant abundance.

\section{Materials and Methods}

\section{Study area}

We sampled ten bays along a 32.6-km stretch of the Cuiabá River downstream from Porto Cercado, in the area of the Private Natural Heritage Reserve (RPPN-SESC Pantanal), Poconé, Mato Grosso, Brazil (Figure 1). Five of the bays were connected to the main channel of the Cuiabá River throughout the four hydrological periods (high water, receding water, dry period, and rising water) in 2009, and are here termed connected bays. The other five bays were connected only 
during the 2009 high-water period, and are here termed periodically connected bays, regardless of the position of the bays downstream and upstream along the river. The regional climate is tropical savannah with dry winters and rainy summers. The temperature ranges from 22 ${ }^{\circ} \mathrm{C}$ to $32{ }^{\circ} \mathrm{C}$ (Hasenack et al. 2003) and rainfall occurs from October to April, with the driest months in June through August. Annual rainfall varies between 1,100 and $1,200 \mathrm{~mm}$, with $85 \%$ falling during the rainy season (Wantzen et al. 2005, Dourojeanni 2006).

\section{Environmental and biological data sampling}

Collections were made quarterly during the 2009 hydrological cycle and corresponded to the four seasonal periods of the Pantanal of Mato Grosso: high water (February/March), receding water (July), dry period (September), and rising water (December). In each bay, three transects were randomly established, with three sampling points each, totaling nine sampling points per bay. The transects were established perpendicular to the shore of the bay and extended from the littoral zone,

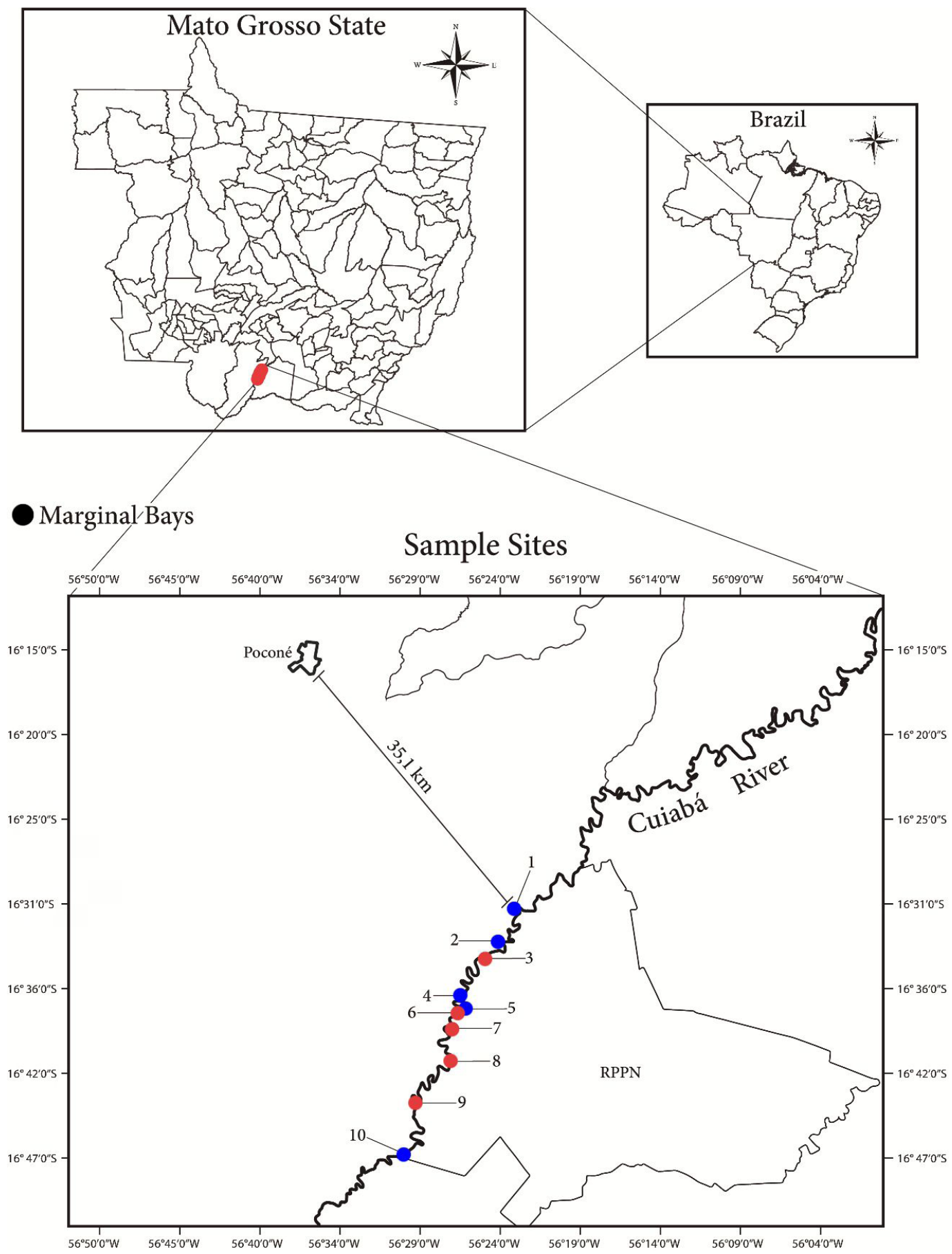

Figure 1. Study area and location of sampling sites along the Cuiabá River, Pantanal of Barão de Melgaço, Mato Grosso. Circles indicate the bays along the Cuiabá River selected for this study. Private Natural Heritage Reserve (RPPN). Blue circle - connected and red circle - periodically connected bays. 
with a saturated substrate, to the area of maximum depth, $3 \mathrm{~m}$ to $5 \mathrm{~m}$ (Thomaz et al. 2003, Fortney et al. 2004). This method ensured that the size of the transects and number of sampling points were standardized in each bay (Brower \& Zar 1984). Sample independence was assumed by establishing minimum distances of $2 \mathrm{~m}$ between each transect and $1 \mathrm{~m}$ between each point.

Limnological and biological variables were measured at each sampling point. Water depth was measured with a graduated ruler, water temperature and electrical conductivity with a Mettler-Toledo MC126 thermistor and conductivity meter, and $\mathrm{pH}$ with a Mettler-Toledo MP120 meter. Plants and weevils were collected using an aluminum cage 0.5 $\mathrm{m}$ square $\times 0.5 \mathrm{~m}$ high with an area of $0.25 \mathrm{~m}^{2}$, screened on the sides, with the bottom open and the upper part with a lid (Vieira \& Adis 1992). The cage was placed over a macrophyte bank, with the upper lid closed, trapping the community of arthropods and macrophytes inside. The lid was then opened, and Salvinia spp. were manually removed, stored in labeled $20 \times 20 \mathrm{~cm}$ plastic bags, and transported to the Advance Base for Pantanal Research (Base Avançada de Pesquisas do Pantanal - BAPP) of the Federal University of Mato Grosso, where they were weighed and fixed in $98 \%$ ethanol for subsequent sorting of insects. The Salvinia fresh mass from each sampling point per $0.25 \mathrm{~m}^{2}$ was used as a measure of coverage and abundance, to quantify the variation across seasonal periods. Weevil adults and larvae were sorted from the ethanol-fixed Salvinia samples under a stereomicroscope. Because the ethanol fixation stimulated the weevils to exit the plant tissues, the Cyrtobagous species could not be accurately associated with Salvinia auriculata and S. minima Baker. Therefore, the plants were evaluated based on the combined fresh mass and were treated in the analyses and discussion as Salvinia spp. This does not affect the interpretation of the results, as both species were present in the macrophyte banks and both are hosts of Cyrtobagous salviniae Hustache, 1929 and Cyrtobagous singularis Calder \& Sands, 1985 (Madeira et al. 2006).

Adults of $C$. singularis and $C$. salviniae were identified based on Calder and Sands (1985), and the larvae were identified based on May (1994) and May and Sands (1986). The vegetation was identified based on the key by Pott and Pott (2000), later confirmed by the specialist Vali Joana Pott, M.Sc. (Embrapa Gado de Corte, Mato Grosso do Sul).

\section{Data analysis}

To evaluate the phenological (adults and larvae) differences in the mean abundances of $C$. salviniae and $C$. singularis, the chi-squared $\left(\chi^{2}\right)$ test was employed for both species together and for each individually. Repeatedmeasures (two-factor) ANOVA was used with and without interactions to explore the temporal effects (among seasonal periods: high water, receding water, dry period, and rising water), spatial variations (between bays), and permanently and periodically connected bay groups on mean abundances of adults and larvae of C. salviniae and C. singularis, fresh weight of Salvinia spp., and limnological variables (water depth, water temperature, $\mathrm{pH}$, and electrical conductivity), considering the points of the three transects as subsamples $(\mathrm{N}=9)$, the bays as sampling units $(\mathrm{N}=10)$, and the hydrological periods $(\mathrm{N}=4)$ and connectivity of bays $(\mathrm{N}=2)$ as treatments. The effect of the hydrological connectivity of bays was analyzed by $t$ test, using the mean abundances of adults and larvae of $C$. salviniae and $C$. singularis and the fresh weight of the Salvinia spp. macrophytes between the permanently and periodically connected bay groups, considering bays $(\mathrm{N}=10)$ as sample units, the seasonal periods as repetitions $(\mathrm{N}=4)$, and the permanently and periodically connected bay groups $(\mathrm{N}=2)$ as treatments.

Spearman correlation was performed between all the predictor variables to detect autocorrelations, and linear regression analyses were used to explore the relationships between the abundances of adults and larvae, biological variables (Salvinia fresh mass), and limnological variables (water depth, water temperature, $\mathrm{pH}$, and electrical conductivity). To determine if the presence and abundance of $C$. salviniae and C. singularis were influenced by the co-occurrence of the species in the sample, the abundance data were transformed to probability of occurrence in the sample, and the probability of occurrence of each species was then analyzed using nonlinear exponential regression. Thus, it was possible to determine if the abundance of one species was related to the proportion of the other. The level of significance adopted in all analyses was 0.05 . The normality assumption was tested by observing distribution probability plots and by the Kolmogorov-Smirnov test, and when appropriate, the raw data were square-root +0.5 transformed. The analyses were performed and the graphs created in SYSTAT 11 (Wilkinson 2004) and SigmaPlot 12.

\section{Results}

A total of 1,790 Cyrtobagous individuals were collected. For the two species combined, larvae (59.94\%) were significantly more abundant than adults $(40.06 \%)\left(\chi^{2}=47.41, \mathrm{df}=18, \mathrm{p}=0.001\right)$. For $C$. salviniae, larval abundance (968 ind., $66.12 \%$ ) was higher than adult abundance (496 ind., 33.88\%) $\left(\chi^{2}=102.64, \mathrm{df}=18, \mathrm{p}=0.001\right)$. For $C$. singularis, adults (221 ind., 67.80\%) were more abundant than larvae (105 ind., $32.20 \%)\left(\chi^{2}=27.91, \mathrm{df}=18, \mathrm{p}=0.001\right)$ (Figure 2).

Only the abundances of $C$. salviniae adults and larvae varied significantly among the four seasonal periods (Figure 3), with the highest larval abundance in the rising-water period and the lowest in the receding-water period. Adults were most abundant during the highwater and least abundant during the dry period. The larval and adult abundances of $C$. singularis were highest in the rising-water period, and gradually decreased during the high-water, receding-water, and dry periods (Figure 4).

The highest abundances of $C$. salviniae and $C$. singularis larvae were recorded in bay 1 and the lowest in bay 7. Adult $C$. salviniae were most abundant in bay 8 and least abundant in bay 7 . The highest abundance of adult $C$. singularis was recorded in bay 2 and the lowest in bay 3. These spatial variations were not significant for either species (Figure 5). The highest larval abundances for both species were recorded in the group of connected bays (Figure 6 and 7). For C. salviniae, the mean abundance in the periodically connected bays was 27.65 and higher in the connected bays, $45.55(\mathrm{t}=-2.95 ; \mathrm{df}=18, \mathrm{p}=0.049)$ for adults and larvae, both together and separately. For $C$. singularis, the mean abundance in the periodically connected bays was 5.65 and in the connected bays was $10.65(\mathrm{t}=-2.74 ; \mathrm{df}=18, \mathrm{p}<0.03)$ for adults and larvae together; only larvae showed a difference in relation to bay connectivity (Figure 7).

The environmental variables of conductivity, $\mathrm{pH}$, water temperature, and water depth, as well as the fresh mass of Salvinia spp. varied significantly between the bays and among the four seasonal periods; only the limnological variables varied between the groups of connected and periodically connected bays (Table 1 ). These variables also showed 


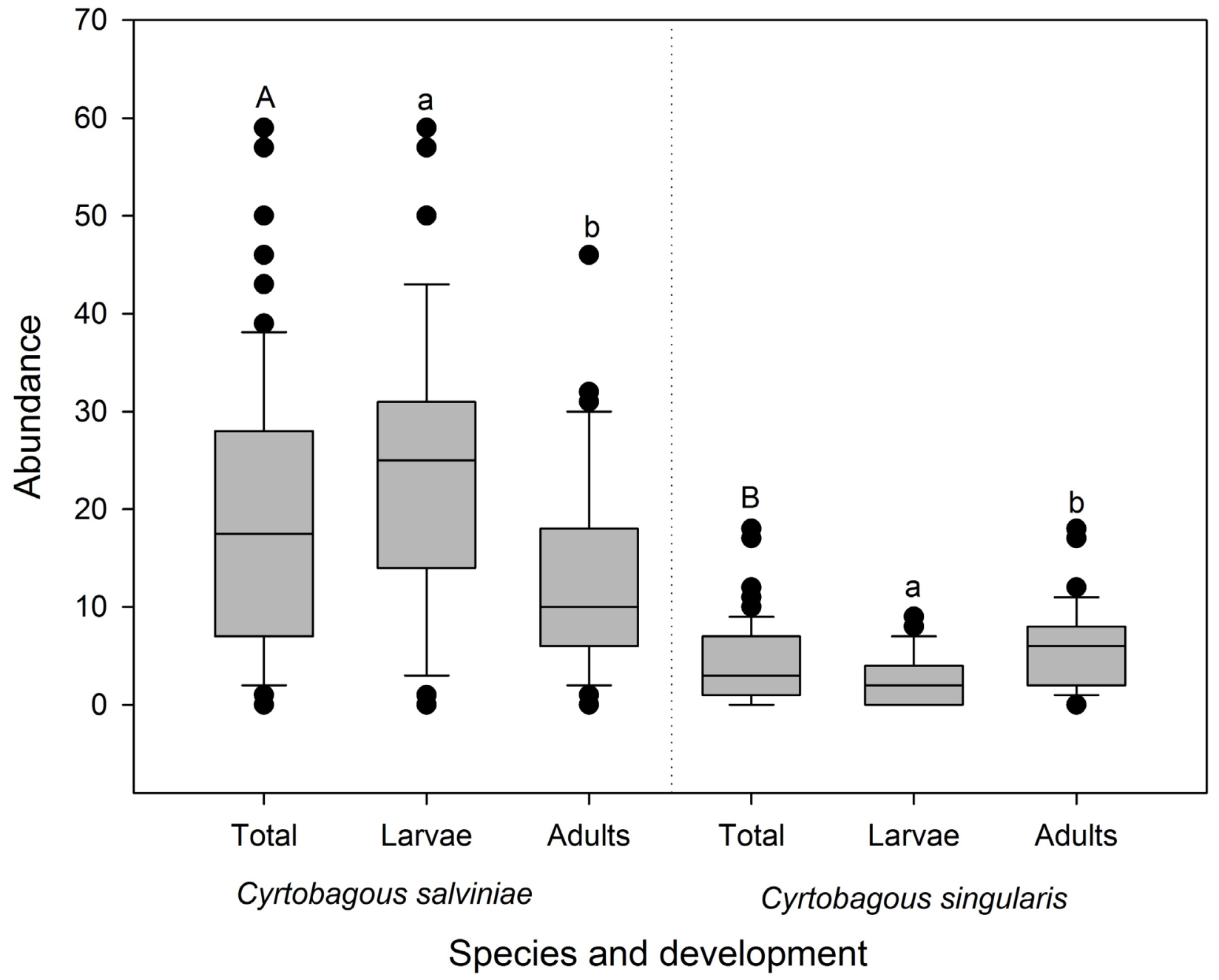

Figure 2. The phenological (adults and larvae) differences in the abundances of Cyrtobagous for both species together and for each individually, collected from bays along the Cuiabá River during a hydrological cycle (2009) in the Pantanal of Barão de Melgaço, Mato Grosso. Different letters indicate significant diferences.

significant interactions between the bays and seasonal periods and between bay connectivity and seasonal periods (Table 1 and 2). The abundances of $C$. salviniae $\left(\mathrm{R}^{2}=0.16, \mathrm{p}<0.01\right)$ and $C$. singularis $\left(\mathrm{R}^{2}=0.35, \mathrm{p}<0.01\right)$ adults and larvae were positively related only to bay water depth and water temperature (Figure 8 and 9). The abundances of adults and larvae of both species were negatively related to conductivity, $\mathrm{pH}$, and fresh mass of Salvinia spp (Figure 8 and 9). No interaction between the variables contributed significantly to explaining the abundances of $C$. salviniae and $C$. singularis adults and larvae.

Cyrtobagous singularis showed a low probability of occurrence in the samples $(10 \%)$, whereas $C$. salviniae was dominant. As the probability of occurrence of C. salviniae increased to more than $30 \%$, the probability of occurrence of $C$. singularis decreased significantly $\left(\mathrm{R}^{2}=0.12, \mathrm{p}<0.05\right)$ (Figure 10); i.e., C. singularis was more frequent when $C$. salviniae was uncommon in the samples.

\section{Discussion}

Our results are consistent with the assumption that the flood pulse is the main factor responsible for regional changes across the seasonal periods (high water, receding water, dry period, and rising water), bay connectivity, and at the local level of the chemical, physical, and biotic components of the aquatic environments of floodplains (Junk et al. 2011) in the abundance of larvae and adults and co-occurrence of the two Cyrtobagous species. Conductivity, $\mathrm{pH}$, water temperature, water depth, and fresh mass of Salvinia spp. varied significantly among seasonal periods and bays, and with connectivity. The seasonal variations in the abundances of $C$. salviniae and $C$. singularis larvae and adults were positively related to the seasonal variations in water depth, water temperature, and connectivity of the bays, confirming our hypothesis that adults and larvae of the two species would be most abundant during high water and in connected bays.

Hydrological seasonality affects the environmental determinants and biomass of aquatic macrophytes, with connectivity and water depth being the main variables (Junk et al. 1989, Junk \& Piedade 1993, Pott \& Pott 2003, Padial et al. 2009, Bornette \& Puijalon 2011, Schneider et al. 2018). In general, aquatic macrophytes are most productive during the rising-water and high-water periods (Pozer \& Nogueira 2004, Nogueira et al. 2011) and show reduced productivity during the receding-water period (Furch \& Junk 1997). Our results for Salvinia fresh mass diverged from this pattern, with the lowest levels of fresh mass obtained in the rising-water and high-water periods and the highest levels in the 
Sousa, W.O., et al.

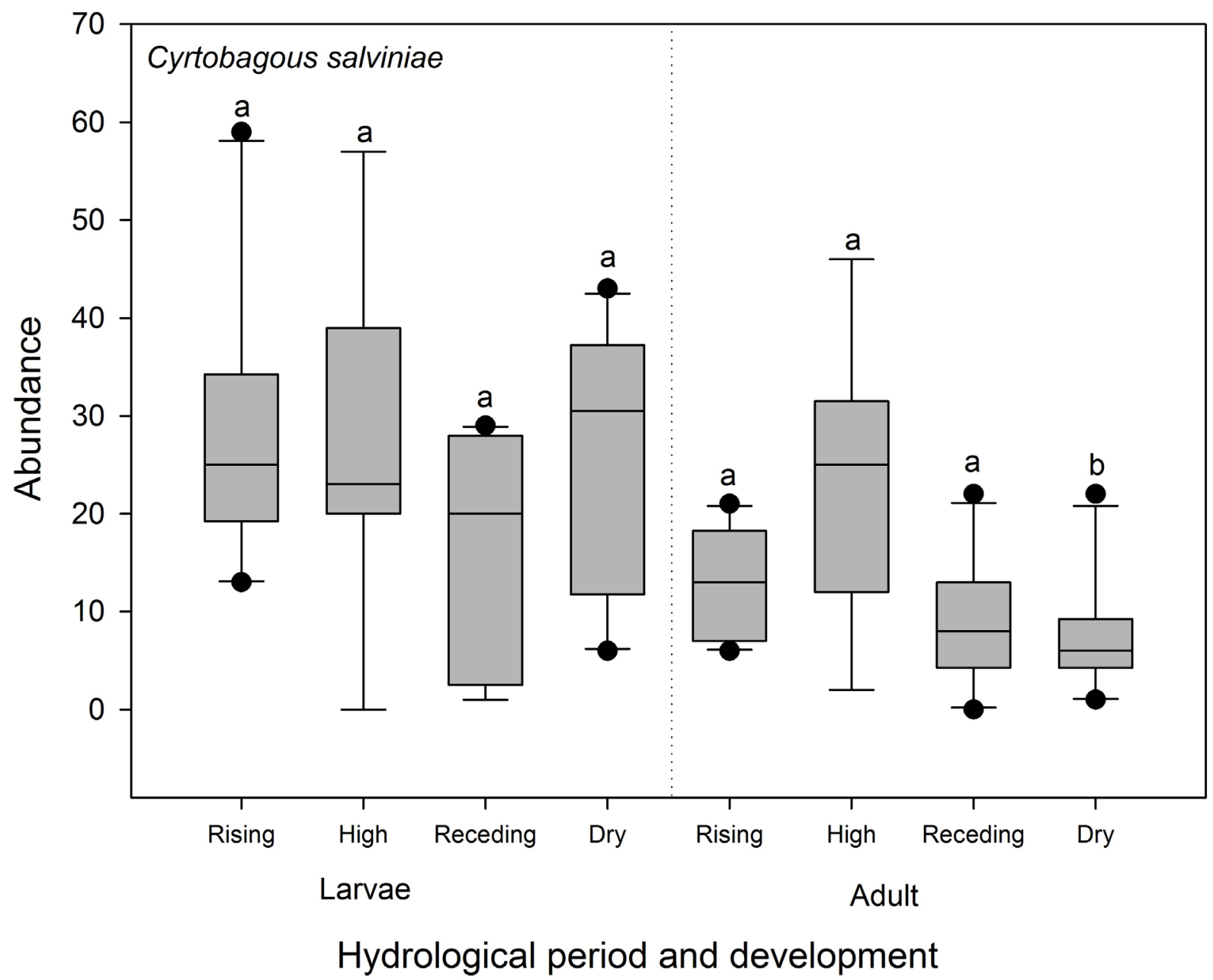

Figure 3. Temporal distribution of abundances of Cyrtobagous salviniae larvae and adults in bays along the Cuiabá River, Pantanal of Barão de Melgaço, Mato Grosso, during the 2009 hydrological cycle. Different letters indicate significant differences.

receding-water and dry periods, contrasting with the greater abundance of larvae and adults of $C$. salviniae and $C$. singularis in the rising-water and high-water periods, which were negatively related to the fresh mass of the host plants. Conditions such as high water-body connectivity and intense flooding tend to increase macrophyte abundance (e.g., Santos \& Thomaz 2008, De Sousa et al. 2011) in certain locations or during certain periods of the hydrological cycle. These conditions may have occurred in the bays studied here, which contributed the largest fresh mass of Salvinia in the receding-water and dry periods. High-water or flooding events severely disrupt the spatial patterns of macrophyte communities, and floating plants tend to drift and can be easily carried out of a water body by currents in high-water periods, resulting in the removal of most of the plant biomass. Such events homogenize floodplain habitats at different spatial scales (Thomaz et al. 2007, De Sousa et al. 2011), leading to decreased fresh mass of Salvinia during high-water periods. Thus, the negative relationship between host-plant biomass and weevil abundance of larvae and adults is not a function of plant biomass, illustrating the complex ecology of phytophagous insects and aquatic plants on the Neotropical floodplain. A lack of relationship or a negative relationship between the abundance of phytophagous insects and the biomass of aquatic macrophytes has been observed in previous studies (e.g., De Sousa et al. 2011, Tipping et al. 2012). This can occur as a function of the delay in the response of the weevil to changes in macrophyte biomass, as supported by ecological theories such optimal foraging (Pyke at al. 1997; Pyke 1984). Since the fresh biomass of the roots of Salvinia spp. is almost 2.5 times larger than the aerial part (Room and Julien 1994), and the receding phase favors colonization and biomass increase of structures such as the roots that are necessary for later investment of aerial biomass due to resource allocation (Medeiros et al., 2016). When larvae and adult weevils are common, however, they are dispersed in the amount of fresh mass of the macrophytes, which then does not reflect the true biomass size of the plant. However, environmental factors that affect populations (e.g., stress factors such as flood pulses) have been identified as potential modulators of interactions between herbivores and plants (Cubit 1984, Menge \& Sutherland 1987, O'Connor 2009, Wood et al. 2017).

Bays with a direct river connection are strongly affected by variations in water level (Neiff \& Poi de Neiff 2003, Santos \& Thomaz 2007). Directly connected bays show pronounced physico-chemical changes over the different hydrological periods, which alters the habitat 


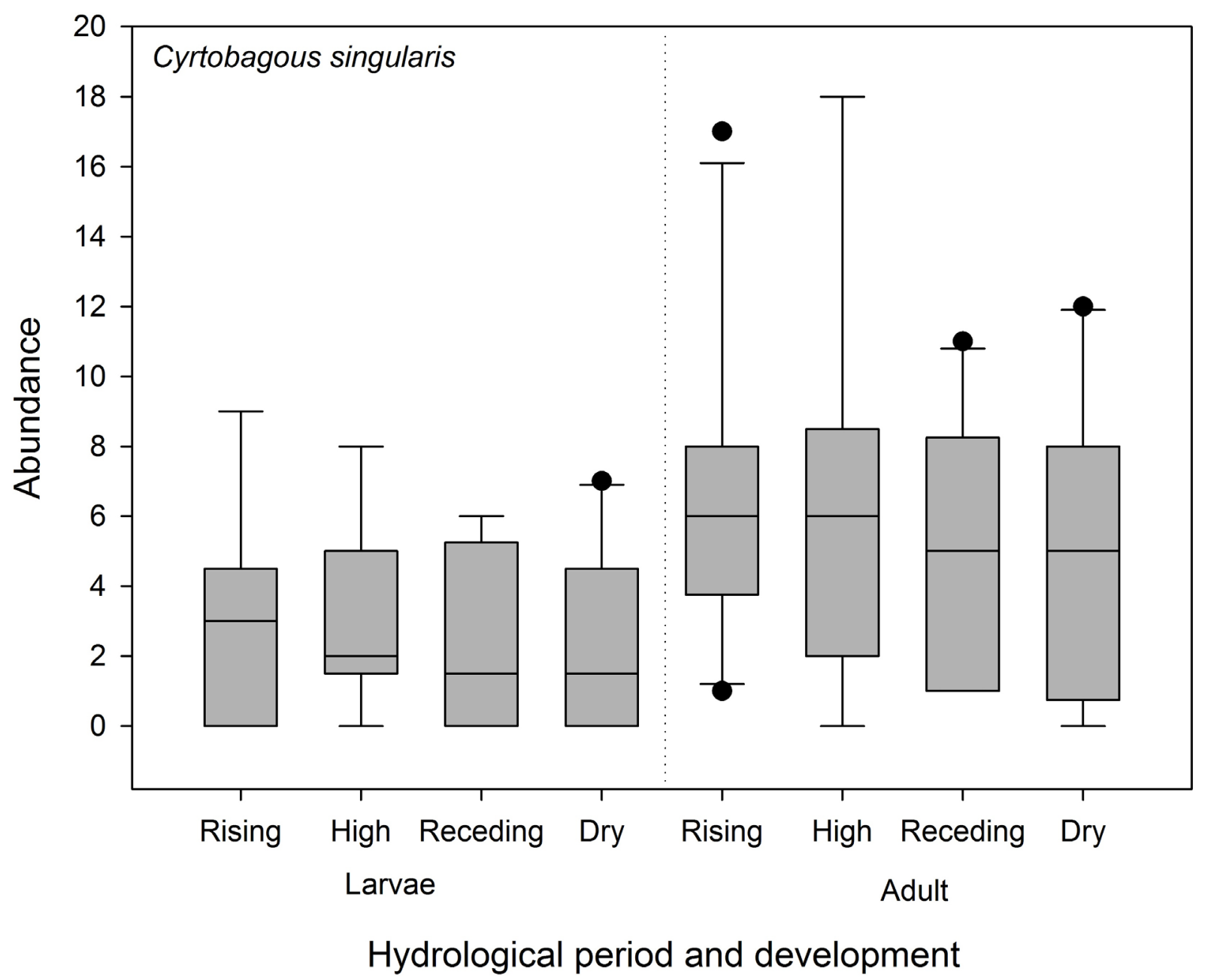

Figure 4. Temporal distribution of abundances of Cyrtobagous singularis larvae and adults in bays along the Cuiabá River, Pantanal of Barão de Melgaço, Mato Grosso, during the 2009 hydrological cycle.

available for groups of animals that use aquatic macrophytes for feeding or reproduction (e.g., Neiff \& Poi de Neiff 2003). These changes promote morphological, anatomical, physiological, phenological, and ethological adaptations in organisms (Junk et al. 2011). The results of this study are consistent with the assumption of a connectivity effect, since the abundances of larval and adult C. salviniae and C. singularis were higher in the permanently connected bays and were related to water depth, reinforcing the effects of the flood pulse and connectivity on the life cycles of these phytophagous insects.

These results also illustrate the effect of the flood pulse on the local factors of conductivity, $\mathrm{pH}$, water temperature, water depth, and fresh mass of Salvinia spp., which varied significantly among the bays (Junk 1997, Neiff \& Poi de Neiff 2003). This finding supports the hypothesis that local factors and bay characteristics such as area and shape (Camargo et al. 2003, Neiff \& Poi de Neiff 2003) influence the environmental characteristics of bays and the spatial distribution and colonization of aquatic macrophytes (Bianchini Jr. 2003, Thomaz \& da Cunha 2010) and the reproductive dynamics of phytophagous insects associated with aquatic vegetation on floodplains. This effect was partially apparent in our study, since the spatial variations in abundance were significant for $C$. salviniae during its entire life cycle, but only for adults of $C$. singularis. The variations were largest in the group of connected bays, supporting our hypothesis of greater abundances of both species of Cyrtobagous in these water bodies.

The flood pulse causes changes across the seasonal periods, leading to phenological adaptations in organisms (Junk et al. 2011). This was apparent in the two Cyrtobagous species: larvae of $C$. salviniae were more abundant than adults, and larvae of $C$. singularis were less abundant than adults and occurred in all four periods, indicating that the flood pulse contributes to the maintenance of populations of Cyrtobagous in bays in the Pantanal of Mato Grosso, favoring more than one reproductive cycle in each of these two populations across seasonal periods (e.g., DeLoach \& Cordo 1976a, Melo et al. 2002, Nunes et al. 2005, Franceschini et al. 2007). The higher abundances and temporal variations in the occurrence of larvae and adult $C$. salviniae indicate that the flood pulse affects the recruitment of individuals on spatial and temporal scales, directly affecting intra- and interspecific competition and resulting in density dependence (e.g., Speight et al. 1999). This is related to longevity and generational overlap in adults (e.g., DeLoach \& Cordo 1976a) and to intraspecific competition in 
Sousa, W.O., et al.

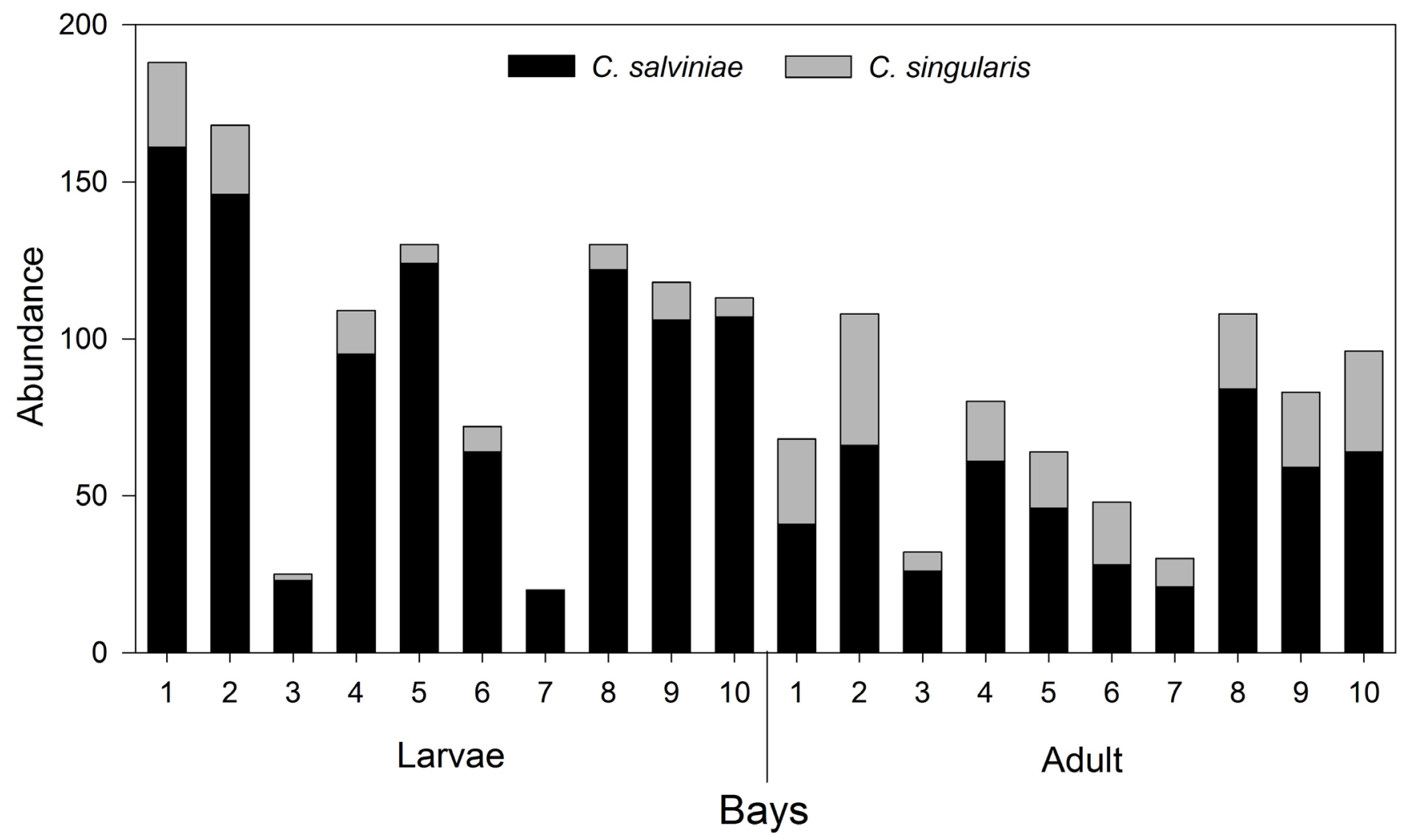

Figure 5. A- Spatial distribution of abundances of Cyrtobagous salviniae and Cyrtobagous singularis larvae and adults in bays (1-10) along the Cuiabá River, Pantanal of Barão de Melgaço, Mato Grosso, during the 2009 hydrological cycle.

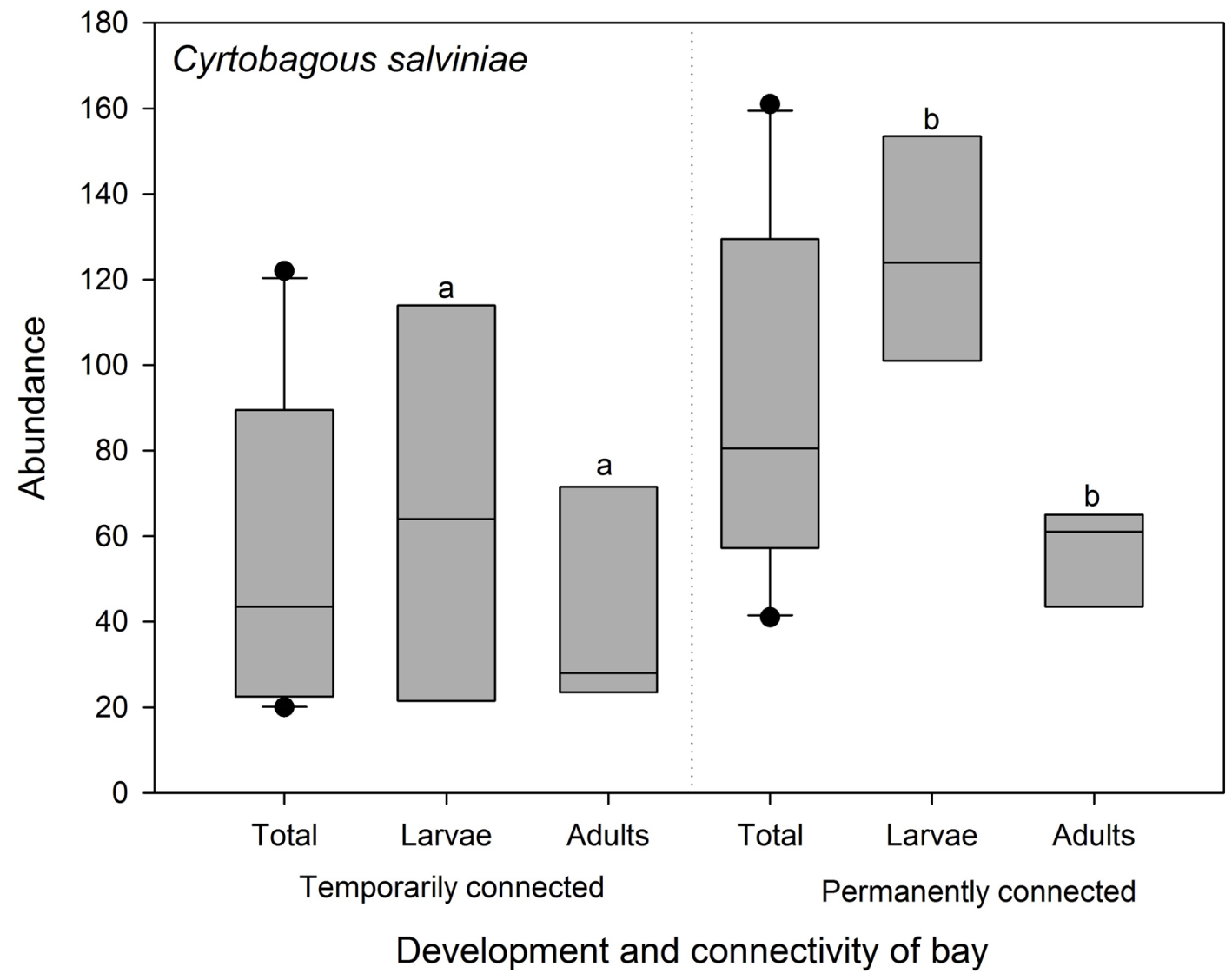

Figure 6. The phenological (adults and larvae) differences in the abundances of Cyrtobagous salviniae in connected and periodically connected bays along the Cuiabá River during a hydrological cycle (2009) in the Pantanal of Barão de Melgaço, Mato Grosso. Different letters indicate significant differences. 


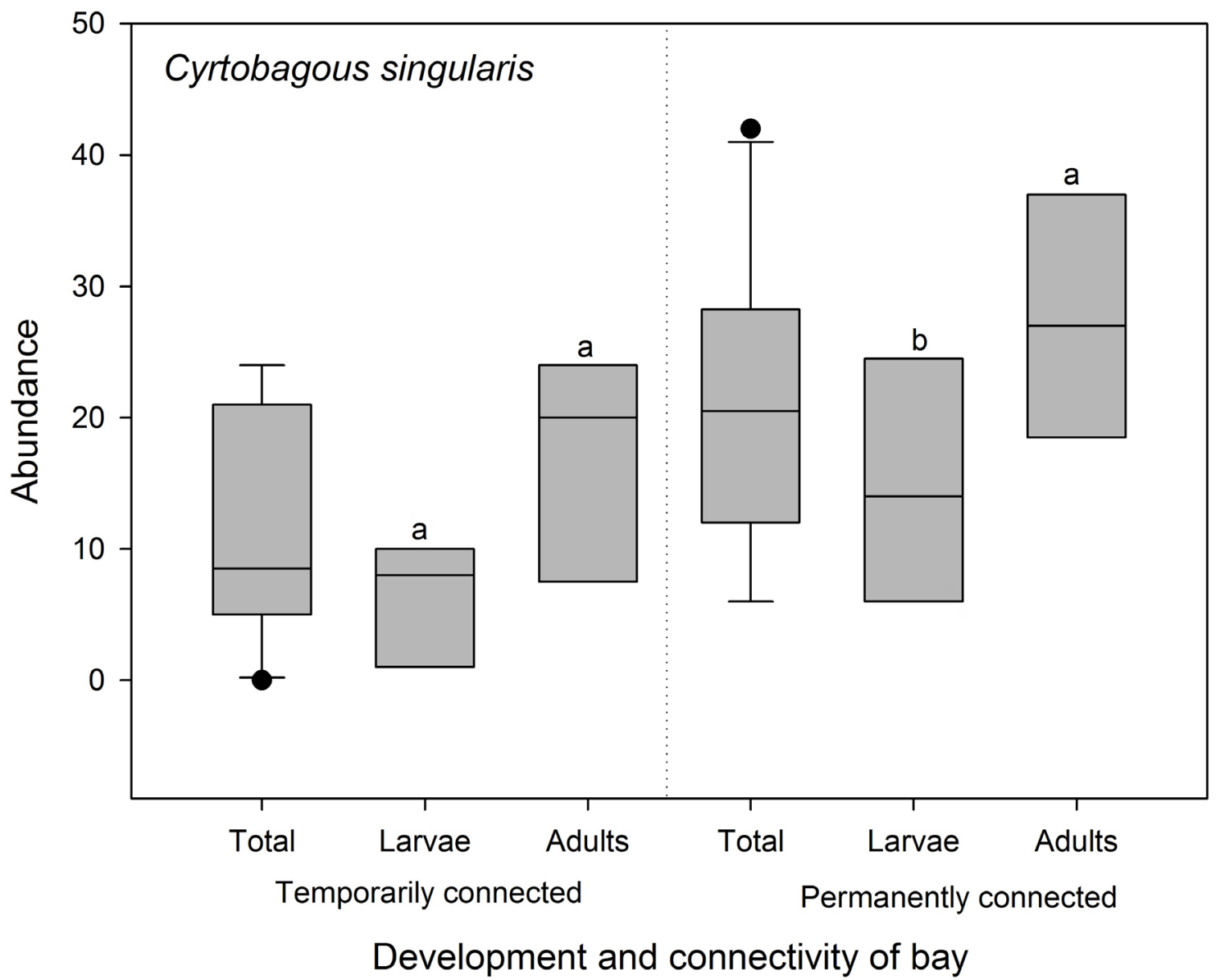

Figure 7. The phenological (adults and larvae) differences in the abundances of Cyrtobagous singularis in connected and periodically connected bays along the Cuiabá River during a hydrological cycle (2009) in the Pantanal of Barão de Melgaço, Mato Grosso. Different letters indicate significant differences.

Table 1. Spatial (bays) and temporal (rising water, high water, receding water, and dry period) effects on the means and standard deviations of environmental and biological variables per bay and seasonal period in the Pantanal of Barão de Melgaço, Mato Grosso. Connectivity: 1 - connected and 0 - periodically connected bays.

\begin{tabular}{|c|c|c|c|c|c|c|}
\hline Connectivity & Bays & Conductivity $(\mu \mathrm{S} \mathrm{cm}-1)$ & pH & Temperature & Depth (m) & Salvinia spp. (Kg) \\
\hline 1 & 1 & $(66.44 \pm 8.28)$ & $(6.00 \pm 2.04)$ & $(29.73 \pm 2.66)$ & $(2.20 \pm 1.01)$ & $(2.28 \pm 9.77)$ \\
\hline 1 & 2 & $(71.33 \pm 10.34)$ & $(6.21 \pm 1.35)$ & $(28.40 \pm 2.11)$ & $(1.46 \pm 0.69)$ & $(3.44 \pm 10.82)$ \\
\hline 1 & 4 & $(72.61 \pm 10.86)$ & $(6.43 \pm 1.04)$ & $(28.28 \pm 2.28)$ & $(1.89 \pm 1.48)$ & $(8.4 \pm 21.51)$ \\
\hline 1 & 5 & $(66.05 \pm 8.88)$ & $(6.74 \pm 0.74)$ & $(28.59 \pm 1.98)$ & $(1.61 \pm 1.44)$ & $(17.32 \pm 28.39)$ \\
\hline 0 & 8 & $(61.33 \pm 11.72)$ & $(6.11 \pm 1.44)$ & $(28.84 \pm 1.81)$ & $(1.53 \pm 0.83)$ & $(8.22 \pm 20.67)$ \\
\hline 0 & 9 & $(73.25 \pm 11.64)$ & $(6.30 \pm 1.42)$ & $(29.00 \pm 2.11)$ & $(1.09 \pm 0.77)$ & $(4.18 \pm 17.42)$ \\
\hline \multirow[t]{7}{*}{1} & 10 & $(66.50 \pm 10.58)$ & $(6.29 \pm 1.37)$ & $(29.31 \pm 2.76)$ & $(1.47 \pm 0.76)$ & $(7.08 \pm 20.90)$ \\
\hline & Bays (p) & $<0.001$ & $<0.001$ & $<0.001$ & $<0.001$ & $<0.05$ \\
\hline & Receding water & $(79.87 \pm 11.84)$ & $(5.56 \pm 0.91)$ & $(25.72 \pm 0.67)$ & $(1.64 \pm 0.61)$ & $(14.54 \pm 26.05)$ \\
\hline & Dry & $(82.99 \pm 19.09)$ & $(8.00 \pm 0.66)$ & $(28.71 \pm 2.07)$ & $(0.71 \pm 0.57)$ & $(9.48 \pm 21.66)$ \\
\hline & Period $(\mathrm{p})$ & $<0.001$ & $<0.001$ & $<0.001$ & $<0.001$ & $<0.001$ \\
\hline & Bays*Period (p) & $<0.001$ & $<0.001$ & $<0.001$ & $<0.001$ & $<0.005$ \\
\hline & Connectivity*Period (p) & $<0.05$ & $<0.005$ & $<0.005$ & $>0.05$ & $>0.05$ \\
\hline
\end{tabular}


Sousa, W.O., et al.

Table 2. Spearman correlation between environmental and biological variables and abundances of adults and larvae of Cyrtobagous salviniae and Cyrtobagous singularis in bays along the Cuiabá River, Pantanal of Barão de Melgaço, Mato Grosso.

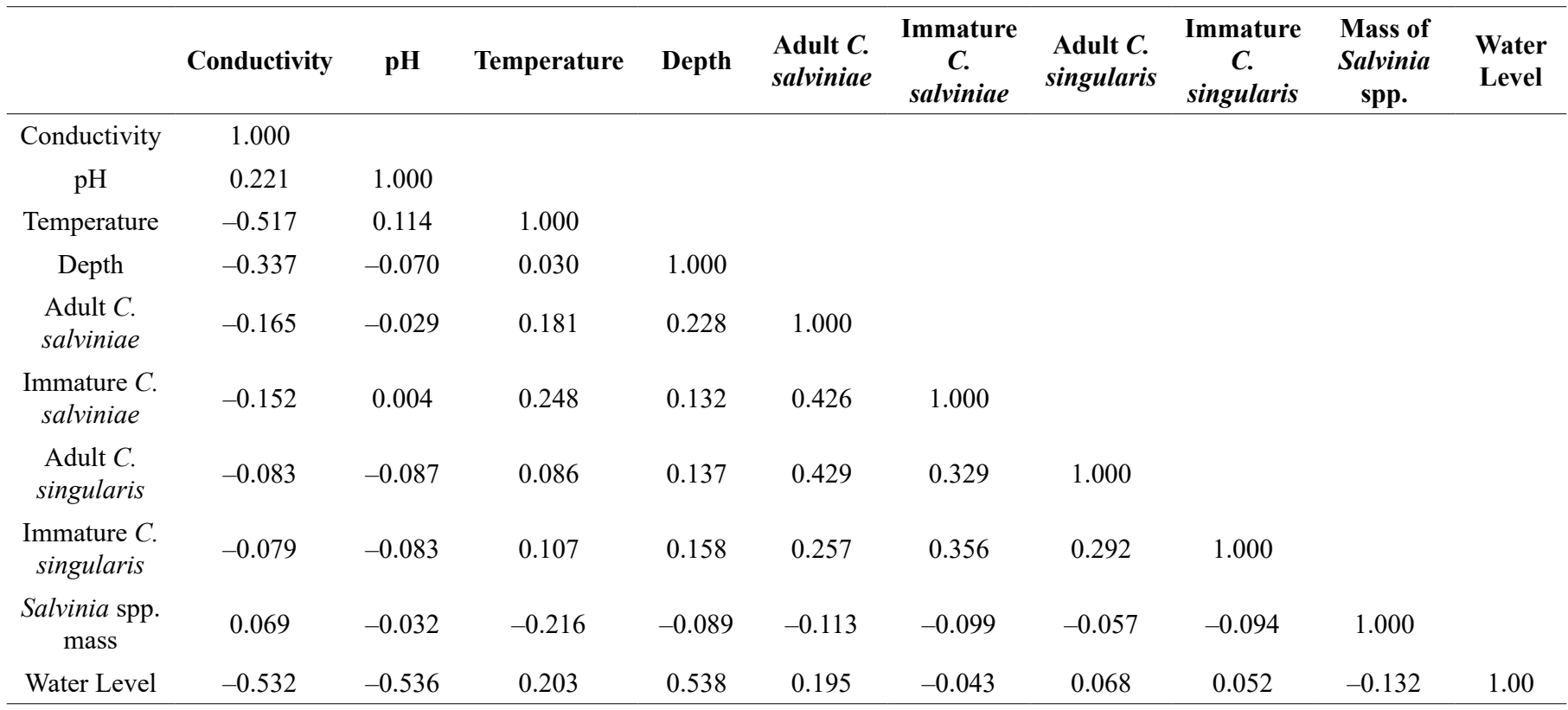
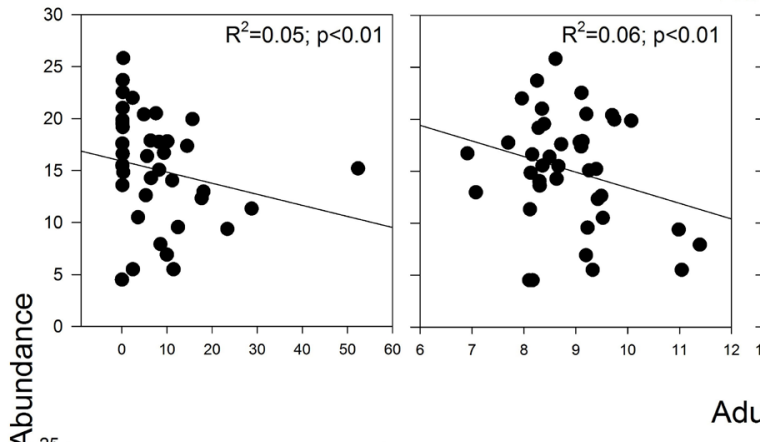

Larvae Cyrtobagous salvinae
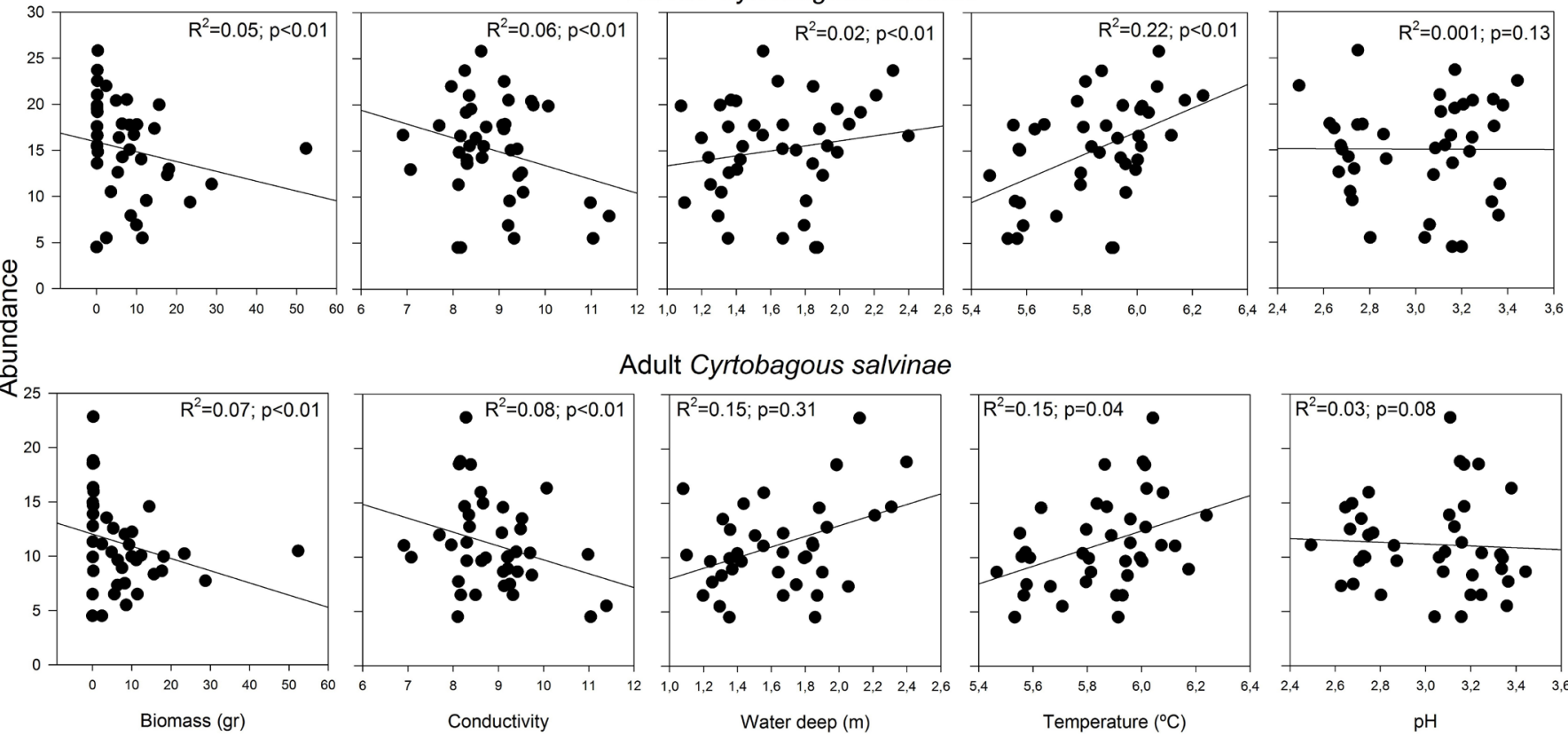

Adult Cyrtobagous salvinae
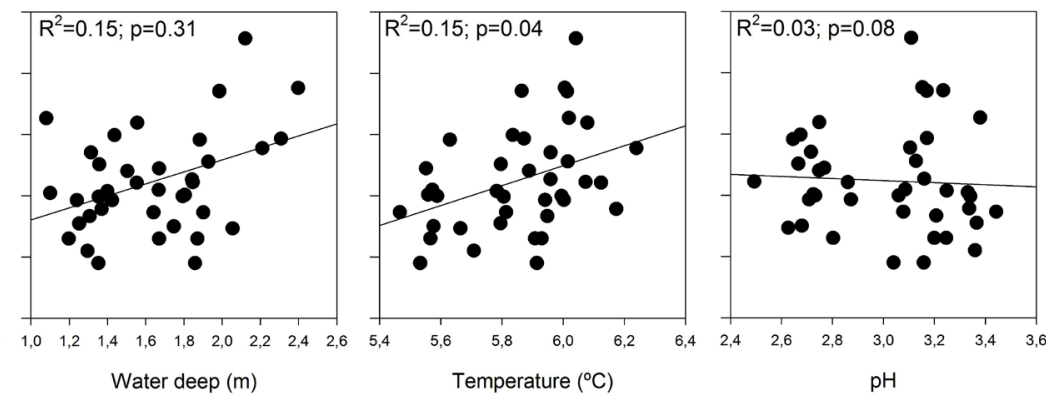

Figure 8. Linear regression between the biological variables (Salvinia fresh mass), limnological variables and abundances of Cyrtobagous salvinae larvae and adults in bays along the Cuiabá River, Pantanal of Barão de Melgaço, Mato Grosso, during the 2009 hydrological cycle.

larvae, which directly influences the birth and death rates in populations (e.g., McNeil et al. 2003), making C. salviniae more competitive than $C$. singularis. The co-occurrence analysis further indicated that $\mathrm{C}$. salviniae is more competitive in banks of Salvinia spp. Other studies of aquatic curculionids have also reported the dominance of one species over another, e.g., Neochetina eichhorniae Warner, 1970 and Neochetina bruchi Hustache, 1926 (DeLoach \& Cordo 1976a, 1976b, De Sousa et al. 2011). These imbalances may be associated with responses to environmental stress conditions as well as to the size and nutritional quality of the host plants (e.g., DeLoach \& Cordo 1976b, Center \&
Dray 1992, Heard \& Winterton 2000, Tipping \& Center 2005), or to preferences for specific oviposition sites (e.g., DeLoach \& Cordo 1976a, 1976b).

Greater competitiveness of $C$. salviniae in banks of Salvinia spp. can also be explained by the biology of the species. Adults of $C$. salviniae are smaller than those of $C$. singularis, and their larvae feed internally in rhizomes (Calder \& Sands 1985); theoretically, they may be less vulnerable to generalist predators, which would likely feed on them despite their smaller size (Tipping et al. 2010). The adults and larvae of $C$. singularis are significantly larger than the adults and larvae of 

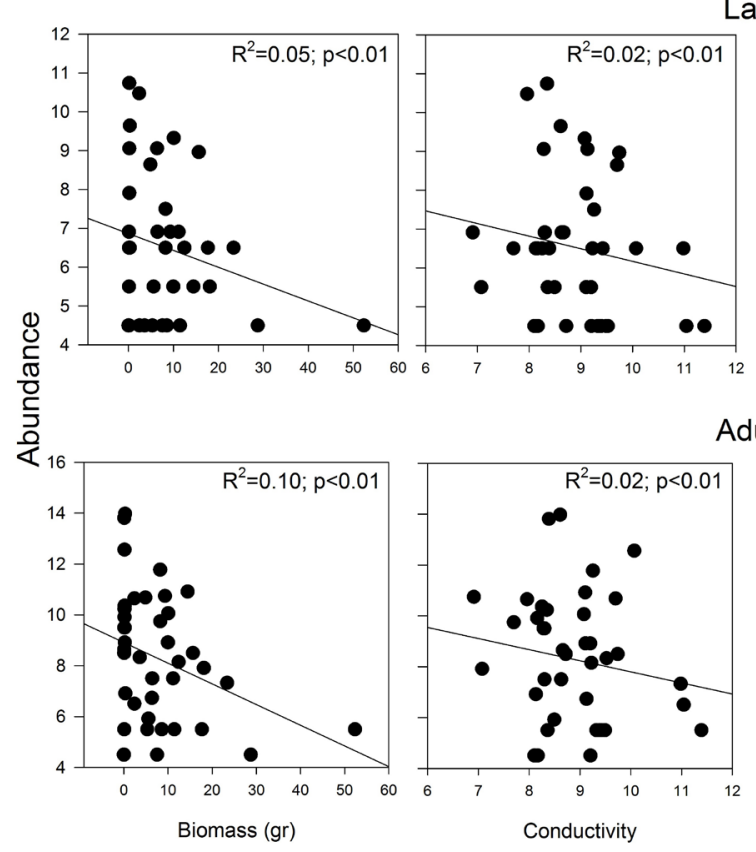

Larvae Cyrtobagous singularis
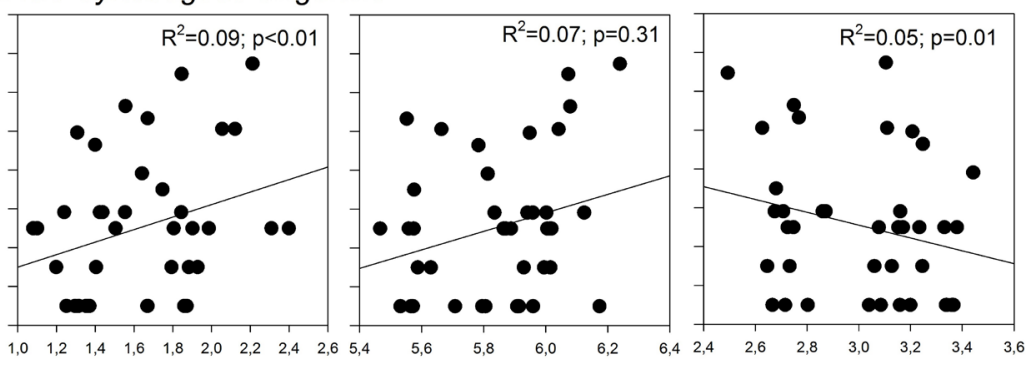

Adult Cyrtobagous singularis
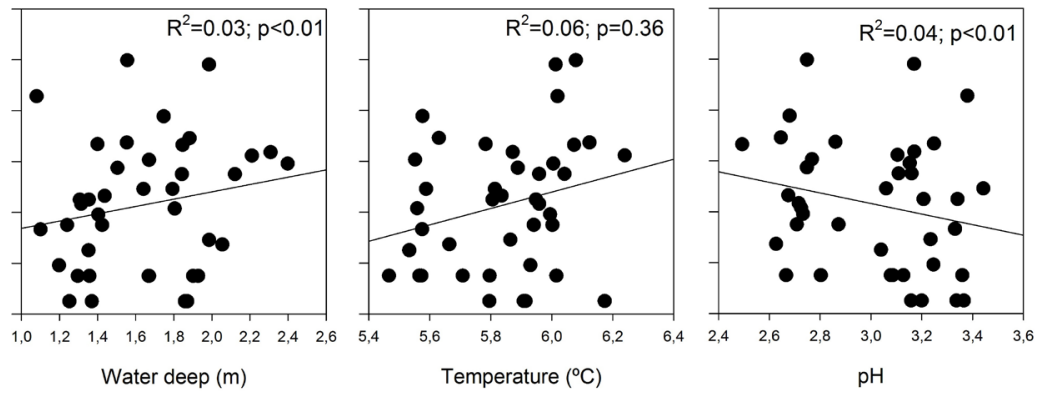

Figure 9. Linear regression between the biological variables (Salvinia fresh mass), limnological variables and abundances of Cyrtobagous singularis larvae and adults in bays along the Cuiabá River, Pantanal of Barão de Melgaço, Mato Grosso, during the 2009 hydrological cycle.

C. salviniae, and the larvae of the former feed externally rather than tunneling in the rhizome (Calder \& Sands 1985, Sands et al. 1986); both attributes may make this species more vulnerable than $C$. salviniae to generalist predators. Furthermore, larger weevil larvae may be more sensitive than smaller larvae to plant size, as larger larvae may not be able to use small, narrow rhizomes, whereas smaller larvae may be able to burrow in a wider range of plant sizes (e.g., Tipping \& Center 2005, Tipping et al. 2010).

Under laboratory conditions, $C$. salviniae laid seven times more eggs than $C$. singularis. These differences, along with differences in the survival of immature individuals, accounted for most of the differences in abundance between these species (Sands et al. 1986). Furthermore, C. salviniae requires favorable environmental conditions for pupation, which occurs in the submerged root hairs (e.g., Forno et al. 1983, Julien et al. 2002). During rising-water and high-water periods, the roots of floating Salvinia accumulate smaller amounts of organic matter and particles than during the other periods, and the physico-chemical characteristics of the water during rising- and high-water periods are more favorable for insect pupation in cocoons among the submerged root hairs. Accordingly, larvae and adults of both species reached higher abundances during the rising-water and high-water periods. The periods of low water levels are unfavorable for pupation among the underwater root hairs for both species, because the shallower water together with the isolation and high abundance of plants reduce water circulation, increase the accumulation of organic debris, and reduce water transparency. The abrupt decreases in oxygen and $\mathrm{pH}$, coupled with the increased phosphorus and nitrogen concentrations in the inner bays likely reflected the storage of organic matter (e.g., De Sousa et al. 2011).

The significant variations in the abundances of larvae and adults of $C$. salviniae among the four seasonal periods demonstrated that the flood pulse influenced the population dynamics of this curculionid.
Because the two species are congeners and probably phylogenetically proximate, the overlap in ecological niche requirements is accentuated, intensifying resource competition, which is further exacerbated by the high population densities in banks of Salvinia spp. In this respect, the data reinforce the supposition that the co-occurrence of these two curculionids can respond to spatial and temporal variations as a function of the hydrological periodicity, through resource partitioning (Kaplan $\&$ Denno 2007). The results suggest that the hydrological periodicity influences the evolutionary divergence of these phytophagous insects, making C. salviniae a superior competitor in a dynamic environment in terms of regional and local adaptations and dispersal ability, while allowing C. singularis to persist at low densities over time (e.g., Batzer \& Wissinger 1996, Rozdilsky \& Stone 2001, Roxburg et al. 2004, Urban et al. 2008).

\section{Acknowledgements}

We thank the Conselho Nacional de Desenvolvimento Científico e Tecnológico $(\mathrm{CNPq})$ for granting a scholarship to the second author. We also thank the Fundação de Amparo à Pesquisa do Estado de Mato Grosso (FAPEMAT), the Coordenação de Aperfeiçoamento de Pessoal de Nível Superior (CAPES) for the Programa Nacional de Pós-Doutorado (PNPD - 1514/2008), the Projeto Ecologia de Longa Duração (PELD-SITE 12), and the Reserva Particular de Patrimônio Natural (RPPN) SESC Pantanal for logistical support. The park guards of RPPN-SESC Pantanal provided invaluable support in the field work. We also thank the research team from the Laboratório de Ecologia e Taxonomia de Artrópodes (LETA) at the Universidade Federal de Mato Grosso for their help with sorting biological material. We are also gratefull to Karl-L. Schuchmann for his special editing support. 
Sousa, W.O., et al.

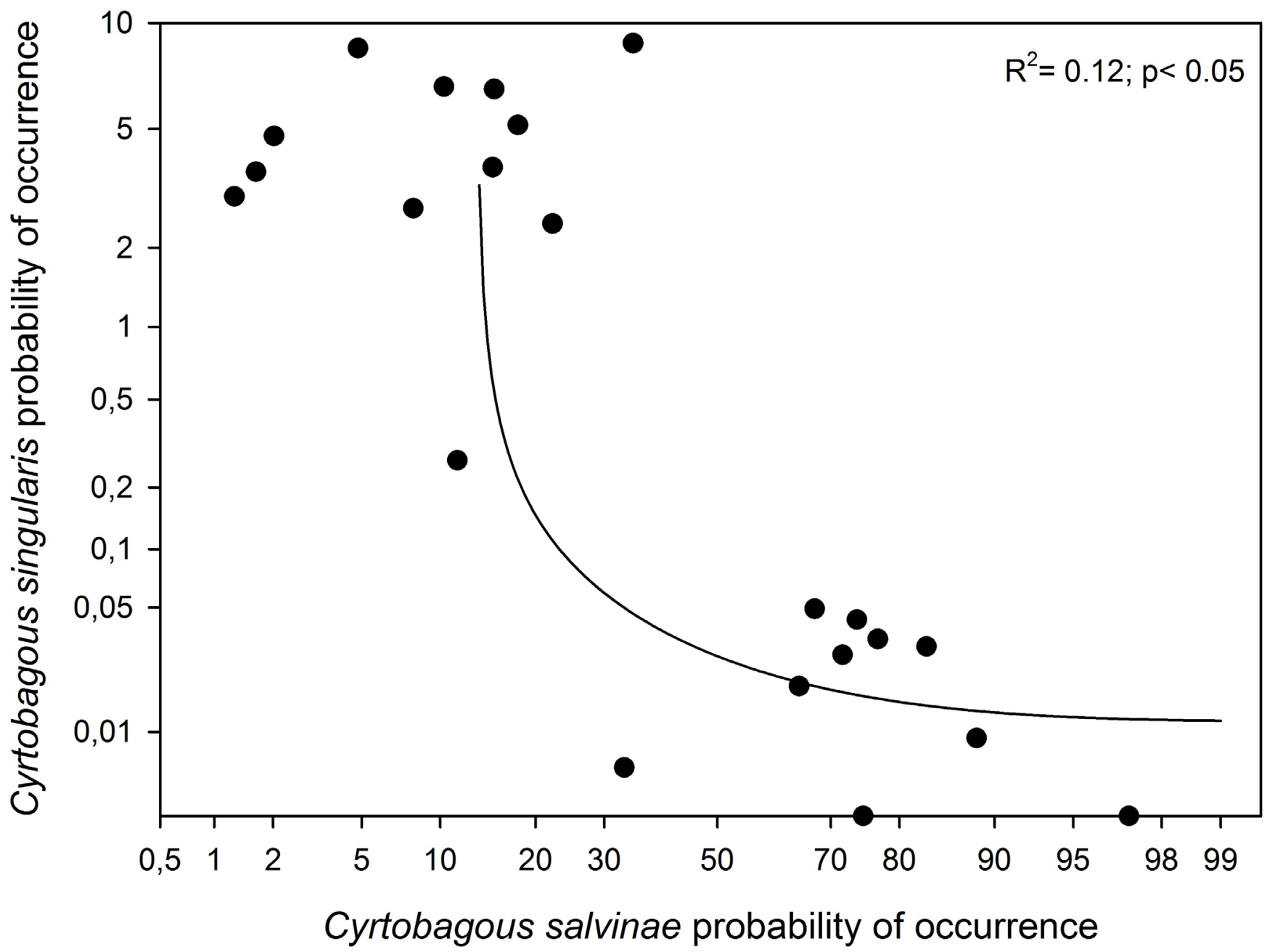

Figure 10. Nonlinear exponential regression of the occurrence probability of Cyrtobagous singularis in the presence of Cyrtobagous salvinae.

\section{Associate Editor}

José Mermudes

\section{Authors Contributions}

Wesley Oliveira de Sousa: substantial contribution in the concept and design of the study; data collection; analysis and interpretation; manuscript preparation and critical revision, adding intellectual content.

Nelson Vinicius Sabino Serra: substantial contribution in the data collection; analysis and interpretation; manuscript preparation and critical revision, adding intellectual content.

Geane Brizzola dos Santos: substantial contribution in the concept and design of the study; data collection; analysis and interpretation; manuscript preparation and critical revision, adding intellectual content.

Rodrigo Aranda: substantial contribution in the analysis and interpretation; manuscript preparation and critical revision, adding intelectual content.

Marinez Isaac Marques: substantial contribution in the concept and design of the study; data collection; analysis and interpretation; manuscript preparation and critical revision, adding intelectual content.
The author(s) declare(s) that they have no conflict of interest related to the publication of this manuscript.

\section{References}

AGOSTINHO, A.A., THOMAZ, S.M., MINTE-VERA, C.V. \& WINEMILLER, K.O. 2000. Biodiversity in the high Paraná River floodplain. In: Biodiversity in Wetlands: assessment, function and conservation (B. Gopal, W. J. Junk \& J. A. Davis, eds), Leiden, Backhuys Publishers, p. 89-118.

ALHO, C.J.R. 2008. Biodiversity of the Pantanal: response to seasonal flooding regime and to environmental degradation. Braz. J. Biol. 68: 957-966. https:// doi.org/10.1590/S1519-69842008000500005.

ALHO, C.J.R. \& SABINO, J. 2011. A conservation agenda for the Pantanal's biodiversity. Braz. J. Biol., 2011, vol. 71, no. 1 (suppl.), p. 327-335. https:// doi.org/10.1590/S1519-69842011000200012

BATZER, D.P. \& WISSINGER, S.A. 1996. Ecology of insect communities in nontidal wetlands. Annu. Rev. Entomol. 41:75-100. https://doi.org/10.1146/ annurev.en.41.010196.000451.

BENETTI, C.J. \& CUETO, J.A.R. 2004. Fauna composition of water beetles (Coleoptera: Adephaga) in seven water environments in the municipality of Gramado, RS, Brazil. Acta Limnol. Bras. 16:1-10.

BIANCHINI, JR.I. 2003. Modelos de crescimento e decomposição de macrófitas aquáticas. In: Ecologia e Manejo de macrófitas aquáticas (S.M. Thomaz \& L.M. Bini, eds), Maringá. p.85-126.

\section{Conflicts of Interest}


BORNETTE, G. \& PUIJALON, S. 2011. Response of aquatic plants to abiotic factors: a review. Aquat. Sci. 73:1-14. https://doi.org/10.1007/s00027-010-0162-7.

BROWER, J.E. \& ZAR, J.H. 1984. Field and laboratory methods for general ecology. Dubuque: Wm. C. Brown Publishers. 226 p.

CALDER, A.A. \& SANDS, D.P.A. 1985. A new brazilian Cyrtobagous Hustache (Coleoptera: Curculionidae) introduced into Australia to control Salvinia. Aust. J. Entomol. 24(1):57-64. https://doi.org/10.1111/j.1440-6055.1985.tb00185.x

CAMARGO, A.F.M., PEZZATO, M.M., \& HENRY-SILVA, G.G. 2003. Fatores limitantes à produção primária de macrófitas aquáticas In: Ecologia e Manejo de macrófitas aquáticas (S.M. Thomaz \& L.M. Bini, eds), Maringá. p. 59-83.

CENTER, T.D. \& DRAY, F.A. 1992. Associations between waterhyacinth weevils (Neochetina eichhorniae and N. bruchi) and phenological stages of Eichhorniae crassipes in southern Florida. Fla. Entomol. 75(2):196-211.

CLEMENTE, J., KROGER, A., GOYENOLA, G., TEIXEIRA-DE-MELLO, F., MARRONI, S., FOSALBA, C., IGLESIAS C. \& MAZZEO, N. 2018. Campsurus violaceus (Ephemeroptera, Polymitarcyidae) in a subtropical reservoir: control factors and relationship with the macroinvertebrate Community. Pan-American Journal of Aquatic Sciences, 13(3): 241-253.

CUBIT, J.D. 1984. Herbivory and the seasonal abundance of algae on a high intertidal rocky shore. Ecology, 65 (6):1904-1917. https://doi. org/10.2307/1937788.

DELOACH, C.J. \& CORDO, H.A. 1976a. Ecological studies of Neochetina bruchi and N. eichhorniae on waterhyacinth in Argentina. Res. Entomol. 14:53-59.

DELOACH, C.J. \& CORDO, H.A. 1976b. Life cycle and biology of Neochetina bruchi, a weevil attacking waterhyacinth in Argentina, with notes on N. eichhorniae. Annu. Entomol. Soc. Am. 69(4): 643-652. https://doi. org/10.1093/aesa/69.4.643.

DE SOUSA, W.O., MARQUES, M.I., ROSADO-NETO, G.H. \& SANTANA, V.T.P. 2011. Dinâmica populacional de duas espécies de Neochetina (Coleoptera: Curculionidae) associadas à Eichhornia crassipes (Pontederiaceae), em lagoas marginais ao rio Cuiabá, Pantanal de Mato Grosso, Brasil. Acta Biol. Parana. 40:55-72. http://dx.doi.org/10.5380/ abpr.v40i(1-4).25214.

DOUROJEANNI, M.J. 2006. Construindo o futuro do Pantanal. Rio de Janeiro: SESC, Departamento Nacional. 303 p.

FORNO, I.W., SANDS, D.P.A. \& SEXTON, W. 1983. Distribution, biology and host specificity of Cyrtobagous singularis Hustache (Coleoptera: Curculionidae) for the biological control of Salvinia molesta. Bull. Entomol. Res. 73 (1): 85-95. https://doi.org/10.1017/S0007485300013821.

FORTNEY, R.H., BENEDICT, M., GOTTGENS, J.F., WALTERS, T.L., LEADY, B.S. \& RENTCH, J. 2004. Aquatic plant community composition and distribution along and inundation gradient at two ecologically distinct sites in the Pantanal region of Brazil. Wetl. Ecol. Manag. 12:575-585. https:// doi.org/10.1007/s11273-005-1763-0.

FRANCESCHINI, M.C., ADIS, J., POI DE NEIFF, A. \& DE WYSIECKI, M.L. 2007. Fenologia de Cornops aquaticum (Orthoptera:Acrididae) em um camalotal de Eichhornia azurea (Pontederiaceae) em Argentina. Amazoniana, 19 (4): 149-158. https://doi.org/10.1590/S1519-566X2010000400011.

FRANCO, G.M. DE SOUZA \& TAKEDA, A.M. 2000. Invertebrate associated with Paspalum repens (Poaceae) at the mouth of Caracu stream (19911992), affluent of the Paraná river, Porto Rico - Pr - Brazil. Braz. Arch. Biol. Tech. 43:317-325.

FRANCO, G.M. DE SOUZA \& TAKEDA, A.M. 2002. Spatial and temporal variation of Odonata larvae associated with macrophytes in two floodplain lakes from the upper Paraná River, Brazil. Acta Scient. 24:345-351.

FURCH, K. \& JUNK, W.J. 1997.The chemical composition, food value, and decomposition of herbaceos plants, leaves, and leaf litter of floodplain forests. In: The Central Amazon Floodplain. Ecological Studies (W.J. JUNK, ed), Berlin, p: 187-205.

GIRARD, P. 2011. Hydrology of surface and ground Waters in the Pantanal floodplains. In: The Pantanal: Ecology, biodiversity and sustainable management of a large neotropical seasonal wetland (Junk, W.J., Da Silva, C.J., Nunes da Cunha, C., Wantzen, K.M. eds)., Pensoft Publishers, SofiaMoscow, p. 103-126.
GOPAL, B., JUNK, W.J. \& DAVIES, J.A. 2001. Biodiversity in wetlands: assessment, function and conservation. volume 2. Leiden, Backhuys Publishers, $311 \mathrm{p}$.

HAMILTON, S.K. 2002. Hydrological controls of ecological structure and function in the Pantanal wetland (Brazil). In: The Ecohydrology of South American Rivers and Wetlands (M. Mcclain, ed.). International Association of Hydrological Sciences Special Publication no. 6. Oxfordshire, p.133-158.

HASENACK, H., CORDEIRO, J.L.P. \& HOFMANN, G.S. 2003. O clima da RPPN SESC Pantanal. Porto Alegre, UFRGS, 30p.

HEARD, T.A. \& WINTERTON, S.L. 2000. Interactions between nutrient status and weevil herbivorous in the biological control of waterhyacinth. J. Appl. Ecol. 37 (1):117-127. http://dx.doi.org/10.1046/j.1365-2664.2000.00480.x.

JULIEN, M.H., CENTER, T.D. \& TIPPING, P.W. 2002. Floating Fern (Salvinia). In: Biological control of invasive plants in the Eastern United States, (Driesche, R.V., Blossey, B., Hoddle, M., Lyon, S. and Reardon, R. eds), Morgantown, p. 17-32.

JUNK, W.J. 1997. General aspects of floodplain ecology with special reference to amazonian floodplains. In: The Central Amazon Floodplain. Ecological Studies (W.J. Junk, ed.), Berlin, Springer, p. 3-20.

JUNK, W.J. \& PIEDADE, M.T.F. 1993. Herbaceous plants of the Amazon floodplain near Manaus: species diversity and adaptations to the flood pulse. Amazoniana, 12 (3/4):467-484.

JUNK, W.J. \& PIEDADE, M.T.F.1997. Plant life in the floodplain with special reference to herbaceous plants. In: The Central Amazon Floodplain. Ecological Studies (W.J. Junk, ed.), Berlin, Springer, p.147-185

JUNK, W.J.\& ROBERTSON, B.A.1997. Aquatic invertebrates. In: The Central Amazon Floodplain. Ecological Studies (W.J. Junk, ed.), Berlin, Springer, p. 279-298.

JUNK, W.J., BAYLEY, P.B. \& SPARKS, R.E. 1989. The flood pulse concept in river-floodplain systems. Can. J. Fish. Aquat. Sci. 106:110-127.

JUNK, W.J., DA CUNHA, C.N., WANTZEN, K.M., PETERMANN, P., STRÜSSMANN, C., MARQUES, M.I. \& ADIS, J. 2006. Biodiversity and its conservation in the Pantanal of Mato Grosso, Brazil. Aquat. Sci. 68:278-309. https://doi.org/10.1007/s00027-006-0851-4.

JUNK, W.J., DA CUNHA, C.N., DA SILVA, C.J., WANTZEN, K.M. 2011. The Pantanal: A large South American wetland and its position in limnological theory. In: The Pantanal: Ecology, biodiversity and sustainable management of a large neotropical seasonal wetland (Junk, W.J., Da Silva, C.J., Nunes da Cunha, C., Wantzen, K.M. eds), (C Pensoft Publishers, Sofia-Moscow, p. 23-44.

KAPLAN, I. \& DENNO, R.F. 2007. Interspecific interactions in phytophagous insects revisited: A quantitative assessment of competition theory. Ecol. Lett. 10 (10):977-994. https://doi.org/10.1111/j.1461-0248.2007.01093.x.

LOYOLA, R.D., BRITO, S. \& FERREIRA, R.L. 2006. Ecosystem disturbances and diversity increase: implications for invertebrate conservation. Biodivers. Conserv. 15: 25-42.

MAY, B.M. 1994. An introduction to the immature stages of Australian Curculionoidea. In: Australian Weevils (Coleoptera: Curculionoidea) Volume II - Brentidae, Eurhynchidae, Apionidae and a Chapter on Immature Stages. (E.C. Zimmerman, ed.), Melbourne, p. 364-721.

MAY, B.M. \& SANDS, D.P.A. 1986. Descriptions of larvae and biology of Cyrtobagous (Coleoptera: Curculionidae): agents for biological control of Salvinia. Proc. Entomol. Soc. Wash. 88:303-312.

MADEIRA, P.T., TIPPING, P.W., GANDOLFO, D.E., CENTER, T.D., VAN. T.K. \& O'BRIEN, C.W. 2006. Molecular and morphological examination of Cyrtobagous sp. collected from Argentina, Paraguay, Brazil, Australia, and Florida. BioControl, 51:679-701. https://doi.org/10.1007/s10526-005-5271-1.

MCNEILL, M.R., PROFFITT, J.R., BARLOW, N.D. \& GOLDSON, S.L. 2003. Population regulation of Argentine stem weevil Listronotus bonariensis (Kuschel) (Coleoptera: Curculionide) in dryland New Zealand pasture: a multitrophic interaction. Environ. Entomol. 32:771-779.

MELO, S.M., TAKEDA, A.M. \& MONKOLSKI, A. 2002 Seasonal dynamics of Callibaetis willineri (Ephemeroptera, Baetidae) associated with Eichhornia azurea (Pontederiaceae) in Guaraná Lake of the Upper Parana River, Brazil. Hydrobiologia, 470:57-62. http://dx.doi.org/10.1023/A:1015617102463 
MELO, S.M., TAKEDA, A.M., GRZYBROWSKA, M. \& MONKOLSKI, A. 2004. Distribution of Ephemeropteran nymphs associated with different stolon section of Eichhornia azurea (Schwartz) in two floodplain lakes of the upper Paraná river (Brazil). Pol. J. Ecol. 52: 355-360.

MENGE, B.A. \& SUTHERLAND, J.P. 1987. Community regulation: variation in disturbance, competition, and predation in relation to environmental stress and recruitment. Am. Nat. 130 (5):730-757. https://doi.org/10.1086/284741.

MURILlO, R.A., ALVES, D.C., MACHADO, R.S., SILVEIRA, M.J., RODRIGUES, K.F. \& THOMAZ, S.M. 2019. Responses of two macrophytes of the genus Polygonum to water level fluctuations and interspecific competition. Aquat. Bot. 157:10-16. https://doi.org/10.1016/j. aquabot.2019.05.003

MURPHY, K.J., DICKINSON, G., THOMAZ, S.M., BINI, L.M., DICK, K., GREAVES, K., KENNEDY, M.P., LIVINGSTONE, S., MCFERRAN, H., MILNE, J.M., OLDROYD, J. \& WINGFIELD, R.A. 2003. Aquatic plant communities and predictors of diversity in a sub-tropical river floodplain: the upper Rio Paraná, Brazil. Aqu. Bot. 77: 257-276.

NEIFF, J.J. \& POI DE NEIFF, A.S. 2003. Connectivity processes as a basis for the management of aquatic plants. In: Ecologia e Manejo de macrófitas aquáticas (S.M. Thomaz \& L.M. Bini, eds), Maringá, p. 39-58.

NUNES, A.L., ADIS, J. \& NUNES DE MELLO, J.A.S. 2005. Fenologia de Phlugis teres (De Geer, 1927) (Orthoptera: Tettigoniidae) e abundância de artrópodos em populações de Eichhornia crassipes (Pontederiaceae) em um lago de várzea da Amazônia Central. Bol. Mus. Par. Emílio Goeldi, ser. Cien. Nat. 1 (2): 271-285.

NOGUEIRA, F.M., SILVEIRA, R.M.L., GIRARD, P., DA SILVA, C. J., ABDO, M., WANTZEN, K.L. 2011. Hydrochemistry of lakes, rivers and groundwater. In: The Pantanal: Ecology, biodiversity and sustainable management of a large neotropical seasonal wetland (Junk, W.J., Da Silva, C.J., Nunes da Cunha, C., Wantzen, K.M. eds), p. 167-198.

O'CONNOR, M.I. 2009. Warming strengthens an herbivore-plant interaction. Ecology, 90 (2): 388-398. https://doi.org/10.1890/08-0034.1.

OLIVEIRA, D., Calheiros, D.F. 2000. Flood pulse influence on phytoplankton communities of the south Pantanal floodplain, Brazil. Hydrobiologia 427, 101-112 . https://doi.org/10.1023/A:100395193052

PADIAL, A.A., CARVALHO, P., THOMAZ, S.M., BOSCHILIA, S.M., RODRIGUES, R.B. \& KOBAYASHI, J.T. 2009. The role of an extreme flood disturbance on macrophyte assemblages in a Neotropical floodplain. Aqu. Sci. 71:389-398. https://doi.org/10.1007/s00027-009-0109-z.

PENATTI, N.C., ALMEIDA, T.I.R., FERREIRA, L.G., ARANTES, A.E. \& COE, M.T. 2015. Satellite-based hydrological dynamics of the world's largest continuous wetland. Remote Sensing of Environment, 170, 1-13. doi:10.1016/j.rse.2015.08.031

POZER, C. \& NOGUEIRA, F. 2004. Flooded native pastures of the Northern Region of the Pantanal of Mato Grosso: biomass and primary productivity variations. Braz. J. Biol., 64(4): 859-866.

POTT, V.J. \& POTT, A. 2000. Plantas aquáticas do Pantanal. Brasília, Embrapa, 404 p.

POTT, V.J. \& POTT, A. 2003. Dinâmica da vegetação aquática do Pantanal. In: Ecologia e Manejo de macrófitas aquáticas (S.M. THOMAZ \& L.M. BINI, eds), Maringá, p. 145-162.

POTT, A., POTT, V.J. 2004. Features and conservation of the Brazilian Pantanal wetland. Wetlands Ecol Manage 12, 547-552. https://doi.org/10.1007/ s11273-005-1754-1

POTT, V.2011. Species diversity, distribution, and biomass of aquatic macrophytes of the Pantanal. In: The Pantanal: Ecology, biodiversity and sustainable management of a large neotropical seasonal wetland (Junk, W.J., Da Silva, C.J., Nunes da Cunha, C., Wantzen, K.M. eds),Pensoft Publishers, Sofia-Moscow, p. 257-279.

PRELLVITZ, L.J. \& ALBERTONI, E.F. 2004. Caracterização temporal da comunidade de macroinvertebrados associada a Salvinia spp. (Salviniaceae) em um arroio da planície costeira de Rio Grande, RS. Acta Biol. Leopol. 2: 213-223.

PYKE, G. H., PULLIAM, H.R., CHARNOV. 1977. Optimal foraging: a selective review of theory and tests. Q. Rev. Biol. 52(2):137-154.

PYKE, G.H. 1984. Optimal foraging theory: a critical review. Ann. Rev. Ecol. Syst. 15 (1): 523-575.
ROXBURG, S.H., SHEA. K. \& WILSON, J.B. 2004. The intermediate disturbance hypothesis: Patch dynamics and mechanisms of species coexistence. Ecology, 85 (2): 359-371. https://doi.org/10.1890/03-0266.

ROZDILSKY, I.D. \& STONE, L. 2001. Complexity can enhance stability in competitive systems. Ecol. Lett. 4 (5):397-400. https://doi.org/10.1046/ j.1461-0248.2001.00249.x.

SANDS, D.P.A., SCHOTZ, M. \& BOURNE, A.S. 1986. A comparative study on the intrinsic rates of increase of Cyrtobagous singularis and C. salviniae on the water weed Salvinia molesta. Entomol. Experim. Appl. 42 (3): 231-237.

SANTOS, A.M. \& THOMAZ, S.M. 2007. Aquatic macrophytes diversity in lagoons of a tropical floodplain: The role of connectivity and water level. Austral Ecol. 32 (2): 177-190. https://doi.org/10.1111/j.1442-9993.2007.01665.x.

SANTOS, A.M. \& THOMAZ, S.M. 2008. Short term fluctuations and succession trends in tropical floodplain vegetation measured by correspondence analysis. Braz. Arch. Biol. Techn. 51 (4):781-791. http://dx.doi.org/10.1590/ S1516-89132008000400016.

SCHNEIDER, B., CUNHA, E.R., MARCHESE, M. \& THOMAZ, S.M. 2018. Associations between macrophyte life forms and environmental and morphometric factors in a large sub-tropical floodplain. Front. Plant. Sci. 19:1-10. https://doi.org/10.3389/fpls.2018.00195.

SPEIGHT, M.R., HUNTER, M.D. \& WATT, A.D. 1999. Ecology of insects: Concepts and applications. London, Blackwell Science Ltd, $350 \mathrm{p}$.

TAKEDA, A.M., SOUZA-FRANCO, G.M., DE MELO, S.M. \& MONKOLSKI, A. 2003. Invertebrados associados às macrófitas aquáticas da planície de inundação do alto rio Paraná (Brasil). In: Ecologia e Manejo de macrófitas aquáticas (S.M. Thomaz \& L.M. Bini, eds), Maringá, p. 243-260.

THOMAZ, S.M., SOUZA, D.C. \& BINI, L.M. 2003. Species richness and beta diversity of aquatic macrophytes in a large subtropical reservoir (Itaipu Reservoir, Brasil): the influence of limnology and morphometry. Hydrobiologia, 505:119-128. https://doi.org/10.1023/ B:HYDR.0000007300.78143.e1.

THOMAZ, S.M., BINI, L.M. \& BOZELLI, R.L. 2007. Floods increase similarity among aquatic habitats in river-floodplain systems. Hydrobiologia, 579:113. https://doi.org/10.1007/s10750-006-0285-y.

THOMAZ, S.M. \& DA CUNHA, E.R. 2010. The role of macrophytes in habitat structuring in aquatic ecosystems: methods of measurement, causes and consequences on animal assemblages' composition and biodiversity. Acta Limnol. Bras. 22 (2):218-236. http://dx.doi.org/10.4322/actalb.02202011.

TIPPING, P.W. \& CENTER, T.D. 2005. Influence of plant size and species on preference of Cyrtobagous salviniae adults from two populations. Biol. Control, 32 (2):263-268. https://doi.org/10.1016/j.biocontrol.2004.10.005.

TIPPING, P.W., MARTIN, M.R., BAUER, L., POKORNY, E. \& CENTER, T.D. 2010. Asymmetric impacts of two herbivore ecotypes on similar host plants. Ecol. Entomol. 35 (4):469-476. http://dx.doi.org/10.1111/j.13652311.2010.01203.x.

TIPPING, P.W., MARTIN, M.R., BAUER, L., PIERCE, R.M. \& CENTER, T.D. 2012. Ecology of common salvinia, Salvinia minima Baker, in southern Florida. Aqu. Bot. 102:23-27. DOI: 10.1016/j.aquabot.2012.04.005.

URBAN, M.C., LEIBOLD, M.A., AMARASEKARE, P., DE MEESTER, L., GOMULKIEWICZ, R., HOCHBERG, M.E., KLAUSMEIER, C.A., LOEUILLE, N., DE MAZANCOURT, C., NORBERG, J., PANTEL, J.H., STRAUSS, S.Y., VELLEND, M. \& WADE, M.J. 2008. The evolutionary ecology of metacommunities. Trends Ecol. Evol. 23 (6):311-7. doi: 10.1016/j.tree.2008.02.007.

VIEIRA, M.F. \& ADIS, J. 1992. Abundância e biomassa de Paulinia acuminata (De Geer, 1773) (Orthoptera: Paulinidae) em um lago de várzea da Amazônia Central. Amazoniana, 12 (2):337-352.

WANTZEN, K.M., DRAGO. E. \& DA SILVA, C.J. 2005. Aquatic habitats of upper Paraguay River-Floodplain-System and parts of the Pantanal (Brazil). Ecohydrol. Hydrobiol.5 (2):107-126.

WANTZEN, K.L., CALLIL, C., BUTTAKA, C.M.M. 2011. Benthic invertebrates of the Pantanal and its tributaries. In: The Pantanal: Ecology, biodiversity and sustainable management of a large neotropical seasonal wetland (Junk, W.J., Da Silva, C.J., Nunes da Cunha, C., Wantzen, K.M. Eds),Pensoft Publishers, Sofia-Moscow , p. 393-430. 
Population dynamics of Cyrtobagous species

WIBMER, G.J. \& O'BRIEN, C.W. 1986. Annotated checklist of the weevils (Curculionidae sensu lato) of South America (Coleoptera: Curculionoidea). Mem. Am. Entomol. Inst. 39, 563p.

WILKINSON, L. 2004. Systat, Version 11.0. San José, Software Inc., USA.

WOOD, K.A., O'HARE, M.T., MCDONALD, C., SEARLE, K.R., DAUNT, F. \& STILLMAN, R.A. 2017. Herbivore regulation of plant abundance in aquatic ecosystems. Biol. Rev. 92 (2): 1128-1141. https://doi.org/10.1111/brv.12272.
ZILLI, F.L. 2012. Life history traits and secondary production of Campsurus violaceus (Ephemeroptera: Polymitarcyidae) in the Paraná River floodplain lakes, Argentina. Stud. Neotrop. Fauna Environ. 47(1): Pages 61-71

Received: 24/06/2021

Accepted: $14 / 01 / 2022$

Published online: 28/02/2022 